\title{
A aplicabilidade da Lei de Improbidade Administrativa aos agentes políticos
}

\author{
The APPLICABILITY OF THE ADMINISTRATIVE \\ IMPROBITY LAW IN RELATION TO POLITICAL AGENTS \\ * Nelia Edna Miranda Batisti \\ ** Júlia Acioli Pimenta
}

Resumo: A aplicabilidade da Lei ${ }^{\circ}$. 8.429/92 (Lei de Improbidade Administrativa) em face dos agentes políticos não é tema pacífico na doutrina e jurisprudência. Há quem sustente que os agentes políticos se submetem à Lei ${ }^{\circ} 1.079 / 50$, que define os crimes de responsabilidade, e, desta forma, não se pode aplicar a Lei de Improbidade Administrativa concomitantemente. Outra corrente defende a sujeição de tais agentes às normas da Lei de Improbidade Administrativa, em razão desta ter natureza jurídica distinta dos crimes de responsabilidade, permitindo, assim, sua aplicação. O presente trabalho tem como finalidade defender a sujeição dos agentes políticos à Lei 8.429/92, baseando-se na ampla análise de entendimentos doutrinários e jurisprudenciais formados em torno do tema sustentando, porém, que a aplicação das sanções previstas na lei deve ser limitada a determinados agentes políticos.

Palavras-chave: Improbidade administrativa. Crimes de responsabilidade. Agentes políticos.

Abstract: The applicability of the Law No. 8.429/92 (Administrative Improbity Law) to the political players is not a pacific subject in the doctrine and court decisions. Some support that the political players are submitted to the Law No. $1.079 / 50$, which defines the responsibility crimes, and, by that, the Administrative Improbity Law could not be applied concomitantly. Other understanding support the subjection of those agents to the rules of the Administrative Improbity Law, on account of this having juridical nature distinct from responsibility crimes, allowing it's application. The present paper has as finality support the subjection of the political players to the Law No. 8.429/92, based on the full analysis of the doctrinal and jurisprudential understandings created around the subject, supporting, however, that the application of the sanctions contained at the Law must be limited to ascertained political players.

Keywords: Administrative Improbity. Responsibility Crimes. Political Players. 


\section{INTRODUÇÃO}

A Lei n ${ }^{\circ} 8.429 / 1992$ é hoje o código de conduta do agente público brasileiro e representou um alento à população ao regulamentar os artigos $37, \S 4^{\circ}$, e 15 , inciso $\mathrm{V}$, ambos da Constituição Federal. Até então, o Brasil não possuía um instrumento legal eficiente e eficaz, capaz de punir e responsabilizar os agentes públicos ímprobos. A partir da Constituição de 1988, com a previsão de responsabilização dos agentes públicos por atos de improbidade administrativa, é que se pensou na edição de uma lei, espelho de normas internacionais, tendo em vista que existia cobrança por uma postura do Brasil para que responsabilizasse - não apenas penalmente, mas também no âmbito civil - os agentes públicos pelos atos ilícitos praticados no exercício de suas funções.

Com o advento da Lei de Improbidade Administrativa, muito se discutiu acerca do seu alcance aos agentes públicos, em especial aos agentes políticos. O principal conflito ocorreu em torno da possibilidade de aplicação das sanções previstas na lei, em razão da prerrogativa de foro que gozam determinados agentes políticos. Isto merece algumas considerações.

Após dez anos da regulamentação da Lei de Improbidade Administrativa, o Congresso Nacional editou a Lei $n^{\circ} 10.628$, em dezembro de 2002, a qual introduziu os parágrafos $1^{\circ}$ e $2^{\circ}$ ao artigo 84 do Código de Processo Penal ${ }^{1}$, estendendo os efeitos da competência especial de foro pela prerrogativa de função dos agentes públicos no âmbito penal, estabelecidos pela Carta Magna, às ações de improbidade administrativa. Ao dar nova redação ao referido artigo, foi reestabelecido o entendimento de que, após o fim do mandato ou encerrada a causa que justificava o foro em virtude da função, o agente público ainda estava atrelado à competência em razão da pessoa, se o crime imputado tivesse sido praticado durante o exercício do cargo ou função. Porém, tal pensamento foi banido com o cancelamento da súmula 394 do Supremo Tribunal Federal, a qual dizia que, cometido o crime durante o exercício funcional, prevaleceria a competência especial por prerrogativa de função, ainda que o inquérito ou a

\footnotetext{
Art. 84. A competência pela prerrogativa de função é do Supremo Tribunal Federal, do Superior Tribunal de Justiça, dos Tribunais Regionais Federais e Tribunais de Justiça dos Estados e do Distrito Federal, relativamente às pessoas que devam responder perante eles por crimes comuns e de responsabilidade. $\S 1^{\circ}$ A competência especial por prerrogativa de função, relativa a atos administrativos do agente, prevalece ainda que o inquérito ou a ação judicial sejam iniciados após a cessação do exercício da função pública. $\S 2^{\circ}$ A ação de improbidade, de que trata a Lei $n^{\circ} 8.429$, de 2 de junho de 1992, será proposta perante o tribunal competente para processar e julgar o funcionário ou autoridade na hipótese de prerrogativa de foro em razão do exercício de função pública, observado o disposto no $\S 1^{\circ}$ (BRASIL, 2002).
}

Revista do Direito Público, Londrina, v.10, n.3, p.119-140, set./dez.2015 | DOI: 10.5433/1980-511X.2015v10n3p119 
ação penal fossem iniciados após a cessação daquele exercício. Este entendimento privilegiava a pessoa do agente e não o cargo, interpretação totalmente contrária ao destino que deve se conceder às normas relativas à competência em razão da função.

No ano de 2006, o Supremo Tribunal Federal declarou inconstitucional a Lei $n^{\circ} 10.628 / 2002$ (ADIN n ${ }^{\circ}$ 2.797-2), inferindo que não pode a lei ordinária pretender impor, como seu objeto imediato, uma interpretação da Constituição. Desse modo, foi reconhecido que o foro por prerrogativa de função não poderia ser estabelecido por lei ordinária, mas sim por emenda constitucional, além de afastar a ideia da extensão do privilégio existente na seara penal para a improbidade administrativa.

Superado esse conflito, passou a ser questionada a possibilidade de aplicação das sanções da Lei de Improbidade Administrativa aos agentes políticos, quando um ato de improbidade administrativa também estiver previsto como crime de responsabilidade.

O Supremo Tribunal Federal, na Reclamação Constitucional 2.138/DF, em 2008, julgou uma ação de improbidade administrativa ajuizada pelo Ministério Público Federal contra o então Ministro de Estado da Ciência e Tecnologia, Ronaldo Mota Sardemberg, por ter usado um avião da Força Aérea Brasileira para fazer viagem de lazer com a família. Após a propositura da ação, o Ministro, em sua defesa, suscitou a impossibilidade de aplicação da Lei de Improbidade Administrativa em razão deste mesmo fato ser previsto em lei específica (a Lei $\mathrm{n}^{\mathrm{o}} 1.079 / 50$ ), a qual prevê crimes de responsabilidade a determinados agentes políticos, e que somente em razão dessa lei é que um Ministro de Estado poderia então ser processado e sofrer sanções como a perda de cargo ou a suspensão de direitos políticos.

Ao final, foi reconhecido no julgamento da referida Reclamação Constitucional a incompatibilidade de aplicar sanções pela Lei de Improbidade Administrativa se o mesmo fato configurar crime de responsabilidade, previsto na Lei $n^{\circ} 1.079 / 50$. Para tanto, invocou-se o princípio da especialidade e foi afastada a possibilidade de aplicação da Lei 8.429/92 a este Ministro de Estado.

Em que pese seja cristalino que tal decisão opera apenas efeitos inter partes, não ostentando efeito geral vinculante, não existe até os dias atuais um posicionamento firmado a respeito do tema que foi discutido na Reclamação Constitucional 2.138/DF, o qual é a problemática central deste estudo.

A fim de melhor compreensão do tema, faz-se necessário analisar os agentes públicos, com ênfase nos agentes políticos, categoria em que se 
concentra a polêmica com relação à aplicação da Lei no 8.249/92.

Para que não haja dúvidas a respeito da distinção entre a Lei de Improbidade Administrativa e os crimes de responsabilidade, serão analisados os atos de improbidade administrativa descritos na lei, desde seus conceitos, quem poderá cometê-los e quem poderá sofrê-los, até as sanções a serem aplicadas. Da mesma forma, serão estudados os crimes de responsabilidade previstos na Lei $n^{\circ} 1.079 / 50$, a fim de que se possa fazer a comparação à Lei de Improbidade Administrativa. Não obstante, o estudo ousará seguir mais adiante para elucidar que as naturezas jurídicas da improbidade administrativa e de suas sanções não se confundem com a dos crimes de responsabilidade.

Por esta razão, este artigo foi desenvolvido com o fito de firmar a tese de que pode existir a aplicação concomitante da Lei 8.249/92 e da Lei n ${ }^{\circ}$ 1.079/50, por possuírem naturezas distintas.

Ademais, será destacada a questão da competência especial de foro em razão da função, além de outras prerrogativas que gozam determinados agentes políticos. Serão analisados o foro competente para processar e julgar eventuais ações civis por ato de improbidade administrativa cometidos por agentes políticos e as restrições existentes acerca da aplicabilidade da Lei 8.429/92 em face de determinados agentes políticos. E a questão basilar ao estudo ora promovido é demonstrar que a Lei de Improbidade Administrativa poderá ser aplicada aos agentes políticos, porém, de forma limitada.

\section{IMPROBIDADE ADMINISTRATIVA}

\subsection{Conceito}

Os administradores públicos têm o dever de prezar pela probidade em atos realizados no exercício de seus cargos, para evitar que sejam responsabilizados por atitudes que estão na contramão do esperado pelos administrados. A probidade significa, em breves palavras, o exercício de qualquer função pública com honestidade, abstendo-se do abuso das prerrogativas inerentes ao cargo público para angariar vantagem ilícita, econômica ou não, para si ou para outrem, da causação de dano patrimonial ou financeiro nos negócios da Administração Pública para particulares, do emprego irregular de verbas públicas e da prática do desvio de finalidade ou do excesso de poder (FIGUEIREDO, 2004, p. 42).

O dever de probidade do administrador público está expresso diretamente no artigo $4^{\circ}$ da Lei $n^{\circ} 8.429 / 92$, que diz: "Os agentes públicos de qualquer nível 
ou hierarquia são obrigados a velar pela estrita observância dos princípios de legalidade, impessoalidade, moralidade e publicidade no trato dos assuntos que lhe são afetos". Esta determinação legal ratifica o que foi consignado no artigo 37 da Constituição Federal.

Assim, é possível compreender que a improbidade administrativa significa a inobservância dos valores morais, no exercício das funções na Administração Pública, com comportamentos desonestos, despidos de integridade e usualmente ofensivos aos direitos de outrem (FAZZIO JÚNIOR, 2008, p. 37).

\subsection{Peculiaridades da $\mathrm{n}^{0} \mathbf{8 . 4 2 9 / 9 2}$}

A Lei Federal $n^{\circ} 8.429 / 92$ classificou os atos de improbidade administrativa em três categorias, ainda que de forma meramente explicativa - não se trata de enumeração taxativa -, considerando os valores jurídicos afetados pela conduta do administrador público no exercício de sua função pública (DI PIETRO, 2013, p. 902). Tais atos podem corresponder a um ato administrativo, a uma omissão ou a uma conduta, e são classificados como: a) atos de improbidade administrativa que importam enriquecimento ilícito (art. $\left.9^{\circ}\right)$; b) atos de improbidade administrativa que causam prejuízo ao erário (art. 10); c) atos de improbidade administrativa que atentam contra os princípios da administração pública (art. 11) - dentre eles, os elencados no artigo 37, caput, da Constituição Federal: legalidade, impessoalidade, moralidade, publicidade e eficiência.

Os sujeitos passivos são os entes públicos lesados pela prática de um ato de improbidade administrativa. Conforme aponta o artigo $1^{\circ}$ da Lei $\mathrm{n}^{\circ} 8.429$ / 1992, as entidades que podem ser atingidas por atos de improbidade administrativa abarcam:

[...] a administração direta, indireta ou fundacional de qualquer dos Poderes da União, dos Estados, do Distrito Federal, dos Municípios, de Território, de empresa incorporada ao patrimônio público ou de entidade para cuja criação ou custeio o erário haja concorrido ou concorra com mais de cinquenta por cento do patrimônio ou da receita anual (BRASIL, 1992).

Assim, como conclui Marino Pazzaglini Filho, "onde houver um único centavo em dinheiro público envolvido, a lei terá incidência, independente de a entidade exercer atividade de natureza pública ou privada" (PAZZAGLINI FILHO, 2007, p. 24).

O sujeito ativo do ato de improbidade administrativa pode ser definido como: 
[...] aquele que pratica o ato de improbidade, concorre para sua prática ou dele extrai vantagens indevidas. É o autor ímprobo da conduta. Em alguns casos, não pratica o ato em si, mas oferece sua colaboração, ciente da desonestidade do comportamento. Em outros, obtém benefícios do ato de improbidade, muito embora sabedor de sua origem escusa (CARVALHO FILHO, 2012, p. 1064).

No artigo $1^{\mathrm{o}}$ da Lei de Improbidade Administrativa estão indicados os sujeitos ativos dos atos de improbidade, quais sejam, os agentes públicos. Desse modo, cabe expor o que a própria Lei n ${ }^{\circ} 8.429 / 1992$ entende por agente público, como dispõe seu artigo $2^{\circ}$ :

Reputa-se agente público, para os efeitos desta lei, todo aquele que exerce, ainda que transitoriamente ou sem remuneração, por eleição, nomeação, designação, contratação ou qualquer outra forma de investidura ou vínculo, mandato, cargo, emprego ou função nas entidades mencionadas no artigo anterior (BRASIL, 1992).

A partir da edição da Lei de Improbidade Administrativa, é possível extrair um conceito mais abrangente de agente público para fins de responsabilização por atos de improbidade administrativa. Ou seja, pode-se dizer que qualquer agente público que de alguma forma se relaciona com o Poder Público, gerindo recursos ou trabalhando com os interesses da Administração Pública, pode ser sujeito ativo dos atos de improbidade administrativa.

Importante salientar que o agente público que praticar qualquer ato ilícito no exercício de sua função, cargo ou emprego está sujeito à responsabilização civil, penal e administrativa. É possível que a mesma conduta configure infração administrativa, acarrete dano à Administração e seja tipificada como crime; neste caso, o servidor arcará com as consequências da responsabilidade administrativa, civil e penal, respectivamente, pois as três têm fundamento e natureza diversos.

Ademais, o artigo $3^{\circ}$ da referida Lei aponta terceiros como sujeitos ativos de atos ímprobos. Vejamos: "as disposições desta lei são aplicáveis, no que couber, àquele que, mesmo não sendo agente público, induza ou concorra para a prática do ato de improbidade ou dele se beneficie sob qualquer forma direta ou indireta" (BRASIL, 1992). Ou seja, terceiros, que não se enquadrem no conceito de agente público, só estarão sujeitos às normas da Lei de Improbidade Administrativa se atuarem em conluio com estes. 
Como uma das espécies de agente público, é possível citar os agentes políticos, os quais são o enfoque deste estudo. Não há um consenso na doutrina a fim de defini-los, porém, alguns autores afirmam que a investidura dos agentes políticos aos cargos, em regra, se dá por meio de eleição - salvo os Ministros e Secretários, que são nomeados -, que lhes garante o direito a um mandato, caracterizados pela transitoriedade do exercício das funções, como pregam as teorias democráticas e republicanas. Ademais, principalmente no que diz respeito às prerrogativas e à responsabilidade política dos agentes políticos, a eles são aplicáveis as regras constantes na Constituição Federal (CARVALHO FILHO, 2012, p. 584).

Neste conceito, compreendem os Chefes do Executivo (Presidente, Governadores, Prefeitos e respectivos vices), seus auxiliares (Ministros e Secretários Estaduais e Municipais) e os membros do Poder Legislativo (Senadores, Deputados Federais, Deputados Estaduais e Vereadores) (MELLO, 2012, p. 252) 2 .

Com efeito, para Maria Sylvia Zanella Di Pietro (2013, p. 586), "a ideia de agente político liga-se, indissociavelmente, à de governo e à de função política, a primeira dando a ideia de órgão (aspecto subjetivo) e, a segunda, de atividade (aspecto objetivo)".

\subsection{Sanções}

Pelo artigo 37, $\S 4^{\circ}$, da Constituição Federal, os atos de improbidade importarão "a suspensão dos direitos políticos, a perda da função pública, a indisponibilidade dos bens e o ressarcimento ao erário, na forma e gradação previstas em lei, sem prejuízo da ação penal cabível” (BRASIL, 1988).

Além do contido na norma constitucional anteriormente mencionada, $\mathrm{o}$ artigo 12 da Lei ${ }^{\circ} 8.429 / 1992$ prevê a perda dos bens ou valores acrescidos ilicitamente ao patrimônio (para a hipótese de enriquecimento ilícito), a multa civil e a proibição de contratar com o Poder Público ou receber benefícios ou incentivos fiscais ou creditícios, direta ou indiretamente, ainda que por intermédio de pessoa jurídica da qual seja sócio majoritário.

A Lei de Improbidade Administrativa também prevê, em seu artigo $8^{\circ}$, a responsabilização do sucessor do agente ímprobo ou do terceiro por atos de improbidade administrativa no que diz respeito ao seu patrimônio. As sanções de caráter pessoal não serão aplicadas, mas aquelas que implicarem a

${ }^{2}$ Conceito mais restrito, também adotado por Maria Sylvia Zanella Di Pietro e José dos Santos Carvalho Filho. 
recomposição de prejuízos ou devolução de valores acrescidos ilicitamente ao patrimônio do agente serão impostas também aos seus sucessores, em caso de morte.

\subsection{Natureza jurídica}

Muito se discute a respeito da natureza jurídica dos atos de improbidade administrativa. Embora algumas das condutas consideradas como atos de improbidade tenham correspondência com tipos penais, como, por exemplo, crimes praticados por funcionários públicos contra a administração pública e de responsabilidade dos prefeitos, os atos de improbidade administrativa não são considerados ilícitos criminais, tendo inquestionável natureza civil, como será demonstrado a seguir.

A princípio, é preciso observar que, conforme foi dito anteriormente, o rol de atos de improbidade administrativa não é taxativo, tratando-se de um conceito jurídico indeterminado, pois diversas condutas podem levar à violação dos princípios da administração pública, por exemplo. Tal indeterminação é incompatível com a tipificação das infrações penais, em observância ao princípio da reserva legal.

Pelo princípio da reserva legal, os tipos penais incriminadores somente podem ser criados por lei em sentido estrito, decorrendo dele o princípio da taxatividade, pelo qual as condutas consideradas infração penal devem ser suficientemente claras e bem elaboradas, de modo a não deixar dúvida por parte do destinatário da norma. Esse cuidado do legislador é plenamente compreensível, em razão da natureza das sanções que uma conduta tipificada penalmente acarreta - a pena privativa de liberdade, de acordo com o art. $1^{\circ}$ do Decreto-Lei $n^{\circ} 3.914$ (Lei de Introdução ao Código Penal), que dispõe: "Considera-se crime a infração penal a que a lei comina pena de reclusão ou de detenção, quer isoladamente, quer alternativa ou cumulativamente com a pena de multa" (BRASIL, 1941).

Com efeito, um ato de improbidade administrativa pode configurar também um ilícito penal. É o que emana da própria redação do já mencionado artigo 37 , $\S 4^{\circ}$, da Constituição Federal, que, após indicar as medidas sancionatórias cabíveis, acrescenta que a lei estabelecerá sua forma e gradação "sem prejuízo de ação penal cabível" (BRASIL, 1988). Ou seja, quando o dispositivo constitucional traz essa ressalva, ele anuncia, sem hesitação, que "as cominações nele declaradas não são substitutivas do conjunto de sanções penais fixado na legislação para os crimes funcionais contra a Administração Pública. Concorrem com eles, sem substituí-los, nem excluí-los” (FAZZIO JÚNIOR, 2008, p. 83). 
De fato, se a própria Carta Magna, como visto, distingue e separa nitidamente a ação condenatória do responsável por atos de improbidade administrativa, e as sanções nela previstas, da ação penal cabível, é inexorável concluir que aquela demanda não ostenta natureza penal.

Outro argumento para afastar a natureza penal dos atos de improbidade administrativa é a previsão do art. $8^{\circ}$ da Lei $n^{\circ} 8.429 / 92$. Ora, sendo possível que algumas das sanções por atos de improbidade administrativa alcancem os herdeiros, faz-se imperioso concluir pela natureza não penal de tais atos, do contrário, ocorreria violação do princípio da intranscendência previsto no art. $5^{\circ}, \mathrm{XLV}$, da Constituição Federal, pelo qual "nenhuma pena passará da pessoa do condenado" (BRASIL, 1988).

Ademais, um ato de improbidade administrativa também pode corresponder a um ilícito administrativo, como ocorre quando um servidor público é o sujeito ativo deste ato, o que obriga a autoridade administrativa competente a instaurar o procedimento adequado para apuração de responsabilidade.

No tocante às sanções previstas na Constituição Federal para os condenados por atos de improbidade administrativa, conquanto elas possam ter consequências na esfera criminal e na esfera administrativa - com a perda da função pública e instauração de processo administrativo -, elas possuem natureza civil e política, porque a comprovação da ocorrência de improbidade administrativa pode implicar, dentre outras medida, a suspensão dos direitos políticos, a indisponibilidade dos bens e o ressarcimento dos danos causados ao erário.

\section{CRIMES DE RESPONSABILIDADE: CONCEITO, NATUREZA JURÍDICA E SANÇÕES}

Esclarece Luís Roberto Barroso que "crimes de responsabilidade são aqueles suscetíveis de ser praticados por determinados agentes políticos, em razão dos cargos públicos que ocupam" (2002, p. 438).

Destarte, os crimes de responsabilidade são infrações políticoadministrativas, consistentes em condutas politicamente indesejáveis e violadoras da Constituição, definidas em lei, cometidas por agentes políticos no desempenho de seu mandato, que atentem contra valores político-administrativos, submetidos a um julgamento feito por órgão político ou legislativo e sujeito às sanções impostas na lei e de natureza política, com a perda do cargo e a inabilitação do exercício da função pública por um tempo determinado. 
Assim, nos dizeres do eminente ministro Celso de Mello, os crimes de responsabilidade:

[...] são infrações político-administrativas definidas na legislação federal, cometidas no desempenho da função, que atentam contra a existência da União, o livre exercício dos Poderes do Estado, a segurança interna do País, a probidade da Administração, a lei orçamentária, o exercício dos direitos políticos, individuais e sociais e o cumprimento das leis e das decisões judiciais. (1980, p. 98).

A prática do crime de responsabilidade enseja responsabilização do agente político mediante existência de um processo adequado e justo, denominado de processo de impeachment, o qual é o instituto de responsabilidade constitucional de agentes políticos, por meio do qual o Poder Legislativo avalia politicamente se a conduta do governante é atentatória aos interesses nacionais.

A previsão constitucional do instituto encontra-se disposta no artigo 52 da Constituição Federal. No plano infraconstitucional, a Lei n ${ }^{\circ}$ 1.079/1950 define os crimes de responsabilidade em relação ao Presidente da República, aos Ministros de Estado, aos Ministros do Supremo Tribunal Federal, ao Procurador Geral da República, aos Governadores e Secretários de Estado. O artigo $2^{\circ}$ desta lei define as sanções e a quem elas podem ser aplicadas em decorrência dos crimes de responsabilidade:

Art. $2^{\circ}$ Os crimes definidos nesta lei, ainda quando simplesmente tentados, são passíveis da pena de perda do cargo, com inabilitação, até cinco anos, para o exercício de qualquer função pública, imposta pelo Senado Federal nos processos contra o Presidente da República ou Ministros de Estado, contra os Ministros do Supremo Tribunal Federal ou contra o Procurador Geral da República (BRASIL, 1950).

O Decreto-Lei n ${ }^{\circ}$ 201/1967 traz, além de disposições tipicamente penais, as hipóteses de crimes de responsabilidade quanto aos Prefeitos e Vereadores.

Os crimes de responsabilidade são de conteúdo estritamente político e, como tais, não possuem qualquer correspondência e não são ao menos extensão do processo criminal.

É possível afirmar que o impeachment é o instrumento pelo qual se procede a perda do cargo e a cassação dos direitos políticos de determinado agente político, em razão da prática de ato definido como crime de responsabilidade. Ressalta-se que, muito embora nos dias de hoje o termo 
impeachment somente é utilizado no caso de crimes de responsabilidade praticados pelo Presidente, verifica-se que seu conceito abrange a todos os agentes políticos que estão sujeitos à prática de crime de responsabilidade.

Assim sendo, uma vez constatada a natureza política do impeachment, resta claro que os crimes de responsabilidade possuem a mesma natureza jurídica, ou seja, visam tão somente à responsabilização política do agente político. Muito embora a terminologia utilizada, o crime de responsabilidade não possui natureza jurídica de ilícito penal, mas sim de infração política, praticadas pelos dignitários da república em ofensa à ordem constitucional.

Conclui-se que os chamados crimes de responsabilidade são infrações que geram sanções político-administrativas, aplicáveis aos agentes políticos definidos na Lei 1.079/1950 e no Decreto-Lei $n^{\circ}$ 201/1967, sendo a demanda processada perante o foro especial da autoridade.

\section{A LEI DE IMPROBIDADE ADMINISTRATIVA E OS CRIMES DE RESPONSABILIDADE}

A aplicabilidade da Lei de Improbidade Administrativa em face dos agentes políticos é objeto de grande discussão. Isto porque surgiram alguns posicionamentos a respeito de que os agentes políticos não se sujeitariam às disposições da referida lei, tendo em vista que eram responsabilizados por meio de um sistema próprio. Ou seja, passaram a defender que todas as infrações cometidas por agentes políticos seriam classificadas como infrações políticoadministrativas e, dessa forma, se encaixariam apenas na legislação definidora dos crimes de responsabilidade.

Para os que sustentam essa tese, a Lei de Improbidade Administrativa e a Lei dos Crimes de Responsabilidade disciplinariam sobre a mesma matéria, qual seja, as infrações político-administrativas cometidas por agentes políticos e, assim sendo, não podem ser aplicadas a eles, tendo em vista que possuem o regime de responsabilidade político-administrativa definido por lei específica (Lei 1.079/1950). Tal posicionamento foi o adotado pelo Supremo Tribunal Federal quando do julgamento da Reclamação 2138/DF no ano de 2007. Vejamos alguns argumentos:

[...] Os atos de improbidade administrativa são tipificados como crime de responsabilidade na Lei $\mathrm{n}^{\circ} 1.079 / 1950$, delito de caráter políticoadministrativo. [...] Distinção entre os regimes de responsabilização políticoadministrativa. O sistema constitucional brasileiro distingue o regime de 
responsabilidade dos agentes políticos dos demais agentes públicos. A Constituição não admite a concorrência entre dois regimes de responsabilidade político-administrativa para os agentes políticos: o previsto no art. $37, \S 4^{\circ}$ (regulado pela Lei $n^{\circ} 8.429 / 1992$ ) e o regime fixado no art. 102, I, "c", (disciplinado pela Lei n ${ }^{\circ} 1.079 / 1950$ ). Se a competência para processar e julgar a ação de improbidade (CF, art. $\left.37, \S 4^{\circ}\right)$ pudesse abranger também atos praticados pelos agentes políticos, submetidos a regime de responsabilidade especial, ter-se-ia uma interpretação ab-rogante do disposto no art. 102, I, “c”, da Constituição. [...] (BRASIL, Supremo Tribunal Federal, 2007).

Com efeito, cabe então ressaltar algumas peculiaridades, inclusive parte delas já debatidas ao longo deste estudo.

A natureza jurídica dos atos de improbidade administrativa é civil conforme evidenciado anteriormente-, de modo que não devem ser confundidos com infrações político-administrativas, como é o caso dos crimes de responsabilidade.

Ademais, "a improbidade administrativa e o crime de responsabilidade são apurados em instâncias diversas e atendem a objetivos também diversos" (DI PIETRO, 2013, p. 901). A Lei 1.079/1950 visa à responsabilização unicamente política do agente por determinada conduta tipificada como infração, no exercício de seu cargo público, ou seja, retirar o poder das mãos daquele que fez mau uso dele, razão pela qual ao agente político eventualmente condenado por crime de responsabilidade são aplicáveis apenas as sanções de perda do cargo e inabilitação para o exercício de funções públicas por oito anos.

Por sua vez a Lei 8.429/1992 pretende combater os atos que atentem contra a probidade da administração, buscando o ressarcimento do dano ao patrimônio público e podendo atingir, inclusive, aqueles que não possuem qualquer vínculo funcional com a Administração Pública.

A Lei de Improbidade Administrativa possui a particularidade de ter seu rol de condutas que configuram atos de improbidade administrativa amplamente tipificado, com penas específicas para cada uma delas, o que não ocorre com os crimes de responsabilidade. A Lei 1.079/1950 disciplina que são crimes de responsabilidade os atos que atentarem contra a probidade da administração, sem especificar condutas, como ocorre na lei de 1992, de modo que são mais abrangentes pela natureza intrinsecamente política de seu processo de apuração.

De fato, as entidades dos crimes de responsabilidade e da improbidade administrativa são distintas e não se excluem, podendo ser processadas 
concomitantemente, em procedimentos autônomos, com resultados absolutamente distintos, embora desencadeados do mesmo fato.

Outro ponto que nos permite pensar dessa forma é que o nosso ordenamento jurídico permite a tramitação de ação penal por crimes comuns para responsabilização por atos, os quais também podem ser matéria de apuração de crime de responsabilidade em processo político, pois as finalidades dos processos de punição são diferentes. Ou seja, é permitida a aplicação da pena privativa de liberdade - que corresponde à penalização mais grave que uma pessoa pode sofrer - por condenação em crime comum, por exemplo, juntamente com as sanções políticas derivadas do processo de apuração de crimes de responsabilidade. Então, se a Constituição Federal permite a coexistência de responsabilização penal e política com relação aos agentes políticos, por qual razão não admitiria a convivência das responsabilizações política e por improbidade administrativa?

Nos casos dos crimes de responsabilidade cometidos pelo Presidente da República e dos cometidos por Ministros de Estado conexos ao Presidente, por exemplo, a Constituição Federal, em seu artigo 52, limita a condenação à perda do cargo e a inabilitação, por oito anos, para o exercício de função pública; porém, adverte: "sem prejuízo das demais sanções judiciais cabíveis" (BRASIL, 1988).

Essa mesma responsabilização concomitante em esferas diversas pode ser encontrada com relação aos agentes públicos em geral, os quais podem ser responsabilizados nas esferas administrativa, penal e civil. Tal entendimento é possível de ser extraído do caput do artigo 12 da Lei de Improbidade Administrativa, o qual dispõe que:

Independentemente das sanções penais, civis e administrativas previstas em legislação específica, está o responsável pelo ato de improbidade administrativa sujeito às seguintes cominações, que podem ser aplicadas isoladas ou cumulativamente, de acordo com a gravidade do fato (BRASIL, 1992).

Sendo assim, leciona a doutrina:

Repita-se, a existência da mesma sanção em áreas diferentes não torna da mesma natureza o processo que as impõe. Na improbidade administrativa $\left(\mathrm{CF}\right.$, art. $\left.37, \S 4^{\circ}\right)$, as sanções, ainda que de suspensão de direitos políticos e de perda da função pública, são hipotéticas, uma vez que o juiz não é obrigado a aplicá-las à luz do princípio da proporcionalidade. Ademais, sua natureza 
não é política, surgida da vontade do parlamento de controlar a onipotência do Executivo ou do Judiciário, como nos crimes de responsabilidade (origem do impeachment); sua natureza é de proteção ao Erário (material ou imaterial), evitando o enriquecimento sem causa e o dano ao patrimônio público à custa do mau desempenho de funções estatais. Ela nada tem a ver com o cunho político dos crimes de responsabilidade, embora existam figuras típicas (abertas) de suas hipóteses na LIA. A natureza civil, penal, administrativa ou política não pode ser deduzida somente com base na sanção aplicada (com exceção da pena privativa de liberdade, exclusiva do direito penal, embora ela exista também na prisão civil), sendo equivocada a confusão da natureza da improbidade administrativa $\left(\mathrm{CF}\right.$, art. $\left.37, \S 4^{\circ}\right)$ com os crimes de responsabilidade que atentam contra a probidade administrativa $(\mathrm{CF}$, art. 85, $\mathrm{V}$ ), somente por terem penas parecidas (uma vez que inabilitação para exercício de cargo não se confunde com a suspensão de direitos políticos, sanção muito mais ampla), ou iguais (perda do cargo) (BIM, 2007, p. 223-224).

Além disso, é razoável dizer que a responsabilidade de um agente político - e, com isso, sua consequente responsabilização - deva aumentar proporcionalmente à sua ascensão hierárquica na Administração Pública. Desse modo, entender que aos agentes políticos mais graduados não cabe a aplicação das duras sanções da Lei de Improbidade Administrativa, e a qualquer outro agente público, efetivo ou comissionado, caberia, é substancialmente contrário a esse pensamento lógico. Nos dizeres de Maria Sylvia Zanella Di Pietro:

Todos os agentes públicos que praticam infrações estão sujeitos a responder nas esferas penal, civil, administrativa e político-administrativa. Nenhuma razão existe para que os agentes políticos escapem à regra, até porque, pela posição que ocupam, têm maior compromisso com a probidade administrativa, sendo razoável que respondam com maior severidade pelas infrações praticadas no exercício de seus cargos (2013,p. 901).

Outrossim, pode-se afirmar que a aplicação da Lei 8.429/1992 em sua máxima eficácia é o meio, aparentemente, mais eficiente para tentar eliminar a corrupção da Administração Pública, pois, como aduziu Sérgio Buarque de Holanda, "no Brasil, pode-se dizer que só excepcionalmente tivemos um sistema administrativo e um corpo de funcionários puramente dedicados a interesses objetivos e fundados nesses interesses" (1995, p. 146). Isto é, retirar a aplicação da Lei de Improbidade Administrativa aos agentes políticos seria um retrocesso no que diz respeito à tentativa de erradicar a corrupção do país, tão debatida e amplamente divulgada nos dias atuais. 
Assim sendo, não assiste razão àqueles que entendem que não é possível haver coabitação entre a responsabilização política e a civil por atos de improbidade administrativa. Entretanto, há uma ressalva a ser levada em consideração quando se discute a aplicação da Lei de Improbidade Administrativa aos agentes políticos.

\section{LIMITAÇÃO DAAPLICAÇÃO DE SANÇÕES DECORRENTES DE ATOS DE IMPROBIDADE ADMINISTRATIVA AOS AGENTES POLÍTICOS}

Análogo ao que já foi abordado, os agentes políticos diferem dos demais agentes públicos, em razão de exercerem suas funções rodeados de prerrogativas que protegem o exercício de seus mandatos. Assim sendo, há algumas restrições à aplicação da Lei 8.429/1992 em face dos agentes políticos, de modo a garantir a essa espécie de agentes públicos o livre exercício de suas funções.

A primeira ressalva pertinente a ser feita é com relação aos parlamentares.

A inviolabilidade, também chamada de imunidade parlamentar, está disposta no artigo 53 da Constituição Federal, com relação aos Deputados e Senadores, o qual diz que eles "são invioláveis, civil e penalmente, por quaisquer de suas opiniões, palavras e votos". Aos Deputados estaduais, essa garantia está descrita no artigo 27, $\S 1^{\circ}$, e aos Vereadores no artigo 29, VIII, todos da Carta Magna, mas para os últimos a inviolabilidade se limita à circunscrição do município.

A cláusula de inviolabilidade constitucional, que impede a responsabilização penal e/ou civil do membro do Congresso Nacional, por suas palavras, opiniões e votos, também abrange, sob seu manto protetor, as entrevistas jornalísticas, a transmissão, para a imprensa, do conteúdo de pronunciamentos ou de relatórios produzidos nas Casas Legislativas e as declarações feitas aos meios de comunicação social, eis que tais manifestações - desde que vinculadas ao desempenho do mandato qualificam-se como natural projeção do exercício das atividades parlamentares (BRASIL, Supremo Tribunal Federal, 2011).

Isto é, ainda que ocorra fato típico descrito na legislação penal, por exemplo, a Constituição exclui sua punição. Assim, se algum parlamentar, no 
exercício de seu mandato, praticar qualquer ato que pudesse ser considerado crime de opinião, não poderá ser responsabilizado nas áreas criminal, civil e administrativa, não podendo, então, aplicar-se a Lei 8.429/1992 (DI PIETRO, 2013, p. 898).

Com relação à imunidade parlamentar, que decorre dos $\S \S 2^{\circ}$ e $3^{\circ}$ do artigo 53 da Constituição Federal, não há o que se falar em impedimento da aplicação de normas referentes à improbidade administrativa, tendo em vista que tratam apenas da responsabilidade criminal dos parlamentares.

Ainda no tocante aos parlamentares, cabe expor outro ponto de controvérsia: a aplicação da sanção de perda da função pública.

Com efeito, do artigo 55 da Carta Maior decorre que é de competência da Câmara dos Deputados ou do Senado a aplicação da sanção de perda do mandato. Porém, o artigo 15, inciso V, da Constituição, inclui a improbidade administrativa, nos termos do artigo $37, \S 4^{\circ}$, como hipótese para a perda ou suspensão dos direitos políticos. Desse modo, nada impede que haja uma ação civil por improbidade administra em face de Deputados - federais e estaduais, por força do artigo $27, \S 1^{\circ}$ da Constituição - e Senadores, com a condenação e imposição da pena de suspensão dos direitos políticos; entretanto, a perda do mandato deverá seguir as normas previstas no artigo $55, \S 3^{\circ}$, da Constituição Federal, que define que "será declarada pela Mesa da Casa respectiva, de ofício ou mediante provocação de qualquer de seus membros ou de partido político representando o Congresso Nacional, assegurada ampla defesa" (BRASIL, 1988).

Por ausência de normas constitucionais, para os Vereadores é possível a aplicação da pena de perda da função pública (DI PIETRO, 2013, p. 899).

Por sua vez, é assunto de bastante divergência a possibilidade de propositura de ação de improbidade e quem terá competência para julgá-la, com a aplicação de todas as suas sanções, em face das autoridades referidas no artigo 52, incisos I e II, da Constituição Federal, o qual dispõe que:

Art. 52. Compete privativamente ao Senado Federal:

I - processar e julgar o Presidente e o Vice-Presidente da República nos crimes de responsabilidade, bem como os Ministros de Estado e os Comandantes da Marinha, do Exército e da Aeronáutica nos crimes da mesma natureza conexos com aqueles;

II - processar e julgar os Ministros do Supremo Tribunal Federal, os membros do Conselho Nacional de Justiça e do Conselho Nacional do Ministério Público, o Procurador-Geral da República e o Advogado-Geral da União nos crimes de responsabilidade; [...] 
Parágrafo único. Nos casos previstos nos incisos I e II, funcionará como Presidente o do Supremo Tribunal Federal, limitando-se a condenação, que somente será proferida por dois terços dos votos do Senado Federal, à perda do cargo, com inabilitação, por oito anos, para o exercício de função pública, sem prejuízo das demais sanções judiciais cabíveis (BRASIL, 1988).

A controvérsia decorre do parágrafo único supracitado, o qual confere competência ao Senado Federal para condenar essas autoridades e aplicar as sanções de perda de cargo e inabilitação para o exercício da função pública. Ou seja, retirou-se do Poder Judiciário a competência para o julgamento dos crimes de responsabilidade praticados pelas autoridades descritas no referido artigo 52, evidenciando sua natureza política. Por meio de uma simples interpretação, poderíamos concluir que, como os atos de improbidade administrativa não são infrações da mesma natureza dos crimes de responsabilidade, estariam fora do alcance do artigo 52.

Porém, é necessário ir além da simples interpretação literal do dispositivo. Cabe ressaltar que a competência para o julgamento de crimes comuns praticados por essas autoridades é do Supremo Tribunal Federal, conforme se extrai do artigo 102, inciso I, da Carta Magna; ou seja, as autoridades possuem foro especial por prerrogativa de função.

O foro por prerrogativa de função tem como principal fundamento a utilidade pública e a maior independência dos Tribunais Superiores, o que aumentaria o grau de imparcialidade na apreciação, bem como minimizaria possíveis pressões políticas que poderiam influenciar os rumos do julgamento.

Nesse sentido, esclarece o eminente Hely Lopes Meirelles:

Realmente, a situação dos que governam e decidem é bem diversa da dos que simplesmente administram e executam encargos técnicos e profissionais, sem responsabilidade de decisão e de opções políticas. Daí porque os agentes políticos precisam de ampla liberdade funcional e maior resguardo para o desempenho de suas funções. As prerrogativas que se concedem aos agentes políticos não são privilégios pessoais; são garantias necessárias ao pleno exercício de suas altas e complexas funções governamentais e decisórias. Sem essas prerrogativas funcionais os agentes políticos ficariam tolhidos na sua liberdade de opção e decisão, ante o temor da responsabilização pelos padrões comuns da culpa civil e do erro técnico a que ficam sujeitos os funcionários profissionalizados. (2004, p. 78). 
Desse modo, faz-se imperioso compreender que se a Constituição Federal se preocupou em fixar a competência para aplicar a sanção de perda do mandato em decorrência dos crimes comuns e dos crimes de responsabilidade ao Supremo Tribunal Federal e ao Senado Federal, respectivamente, para aqueles praticados pelas autoridades descritas nos incisos I e II do seu artigo 52, é razoável dizer que, para que haja a aplicação da mesma sanção de perda de cargo, nesse caso imposta por processo de improbidade administrativa, seja também necessária a apreciação do Senado.

O legislador constituinte certamente teve por objetivo impedir que os crimes praticados por autoridades de tão alto nível, podendo levar à perda do cargo, fossem julgados por autoridade outra que não o STF (para os crimes comuns) e o Senado Federal (para os crimes de responsabilidade). Não teria sentido que essa mesma pena de perda do cargo, em caso de improbidade que não caracterize crime, pudesse resultar em perda do cargo imposta por outra autoridade de nível inferior. (DI PIETRO, 2013, p. 899).

Além disso, a aplicação da sanção de perda de mandato pelo Senado Federal garante a preservação da estabilidade político-institucional do Estado, na qual não cabe à Lei 8.429/1992 intervir.

Enfim, tais considerações não significam que ao mais alto nível de autoridades de agentes políticos não se aplique a Lei de Improbidade Administrativa. O que se defende é a sua aplicação de forma limitada, pois, da ação que condenar o agente por ato de improbidade administrativa, não poderá resultar a aplicação da sanção de perda do cargo, tendo em vista que é de competência do Senado Federal a aplicação da pena de perda do cargo com inabilitação, por oito anos, para o exercício da função pública, sem prejuízo das demais sanções judiciais cabíveis (como as que decorrem da prática de crime comum ou ilícitos civis, como é o caso da improbidade administrativa).

Esse posicionamento é o adotado pelo Superior Tribunal de Justiça. Como exemplo, podemos citar parte da ementa do Recurso Especial No 1.484 .674 PI (2014/0188118-8), cujo relator foi o Ministro Humberto Martins:

[...] Inexiste foro por prerrogativa de função a agentes políticos processados por ato de improbidade administrativa, salvo em relação àquelas autoridades elencadas no art. 102, 1, c, da CF188 (ADI 2797/DF e 28601DF). 3. ALei de Improbidade Administrativa aplica-se aos agentes políticos, tendo em vista que a Reclamação 2.138-6IDF - STF foi decidida em controle abstrato de 
constitucionalidade, não possuindo, assim, efeito vinculante ou eficácia erga omnes. Precedentes do STJ e desta Corte. [...] (BRASIL, Superior Tribunal de Justiça, 2014).

Desta feita, é de se esperar que esse entendimento acabe por predominar, pois eximir os agentes políticos da responsabilização por atos de improbidade administrativa anularia conquistas históricas para o combate ao mau uso das atribuições que são conferidas a esses agentes, e seria consequente facilitador da violação dos princípios constitucionais da Administração Pública.

\section{CONSIDERAÇÕES FINAIS}

É possível extrair do presente estudo que a Lei de Improbidade Administrativa é aplicável aos agentes políticos, os quais são uma categoria de agentes públicos essencial para o funcionamento da Administração Pública.

A Lei de Improbidade Administrativa foi editada com o escopo de regulamentar o artigo $37, \S 4^{\circ}$, da Constituição Federal, o qual também visava à reparação dos danos causados ao patrimônio público pelos atos de improbidade administrativa praticados pelos agentes públicos, estipulando também princípios a serem estritamente seguidos por eles, para que se alcance uma administração pautada na moralidade e honestidade.

Por sua vez, os crimes de responsabilidade são regulados pela Lei ${ }^{\circ}$ 1.079/1950 e seu processo de apuração, denominado impeachment, tem a finalidade de responsabilizar politicamente o agente político pelas condutas que atentem contra a segurança nacional, a estrutura e forma do Governo e a separação dos poderes. Este processo é um instrumento colocado à disposição do Poder Legislativo para apurar condutas ilícitas no âmbito políticoadministrativo, o qual tem como fim único a retirada do poder do agente político infiel.

Como exaustivamente demonstrado, os atos de improbidade administrativa possuem natureza civil e, portanto, não se confundem com os crimes de responsabilidade, que possuem natureza político-administrativa. Assim sendo, um mesmo ato praticado por um agente político pode gerar responsabilização por improbidade administrativa e por crime de responsabilidade, concomitantemente.

Desta forma, a previsão de responsabilização política do agente pela sistemática do crime de responsabilidade não afasta a responsabilidade civil do 
agente político pelos danos causados à Administração Pública por sua conduta ímproba, haja vista que em nosso sistema jurídico vigora como verdadeiro axioma a independência das instâncias.

Porém, percebe-se que a aplicação das sanções previstas na Lei de Improbidade Administrativa deve ser limitada com relação aos agentes políticos descritos nos artigos 52, incisos I e II, e 102, inciso I, alínea “c”, ambos da Constituição Federal, devendo ser respeitada a competência especial de foro por prerrogativa de função a qual gozam tais agentes.

A consideração feita não induz a pensar que os agentes políticos não sejam alcançados pela Lei de Improbidade Administrativa; pelo contrário, os agentes políticos que cometerem atos de improbidade administrativa que importem enriquecimento ilícito, causem prejuízo ao erário ou que atentem contra os princípios da administração pública deverão ser responsabilizados civilmente pelos danos causados.

\section{REFERÊNCIAS}

BARROSO, Luís Roberto. Temas de direito constitucional. 2. ed. Rio de Janeiro: Renovar, 2002.

BIM, Eduardo Fortunato. A possibilidade de cumulação dos crimes de responsabilidade (impeachment) e da improbidade administrativa dos agentes políticos por distinção de suas naturezas jurídicas. Revista de Direito do Estado, Rio de Janeiro, ano 2, n. 5, p. 223-224, jan./mar. 2007.

\section{BRASIL. Constituição da República Federativa do Brasil de 1988.}

Disponível em: $<$ http://www.planalto.gov.br/ccivil_03/constituicao/ constituicao.htm>. Acesso em: 12 jan. 2015.

. Decreto-Lei $\mathbf{n}^{\mathbf{0}} \mathbf{2 . 8 4 8}$, de 7 de dezembro de 1940. Código Penal. Disponível em: < http://www.planalto.gov.br/ccivil_03/decreto-lei/ del2848.htm>. Acesso em: 12 jan. 2015.

. Decreto-Lei no 3.914, de 9 de dezembro de 1941. Lei de introdução do Código Penal (decreto-lei n. 2.848, de 7-12-940) e da Lei das Contravenções Penais (decreto-lei n. 3.688, de 3 outubro de 1941). Disponível em: < http://www.planalto.gov.br/ccivil_03/decreto-lei/ del3914.htm>. Acesso em 13 fev. 2015. 
. Lei $\mathbf{n}^{\mathbf{0}} \mathbf{1 0 . 6 2 8}$, de 24 de dezembro de 2002. Altera a redação do art. 84 do Decreto-Lei no 3.689, de 3 de outubro de 1941 - Código de Processo Penal. Disponível em: <http://www.planalto.gov.br/ccivil_03/leis/ 2002/L10628.htm>. Acesso em: 11 abr. 2015.

. Lei $\mathbf{n}^{\mathbf{0}}$ 8.429, de 2 de junho de 1992. Dispõe sobre as sanções aplicáveis aos agentes públicos nos casos de enriquecimento ilícito no exercício de mandato, cargo, emprego ou função na administração pública direta, indireta ou fundacional e dá outras providências. Disponível em: $<$ http:/ /www.planalto.gov.br/ccivil_03/leis/18429.htm>. Acesso em: 3 fev. 2015.

. Lei $\mathbf{n}^{0}$ 1.079, de 10 de abril de 1950. Define os crimes de responsabilidade e regula o respectivo processo de julgamento. Disponível em: <http:/www.planalto.gov.br/ccivil_03/LEIS/L1079.htm>. Acesso em: 3 fev. 2015.

. Superior Tribunal de Justiça. Recurso especial:1484674 PI 2014/0188118-8. Relator: Ministro Humberto Martins. Data de Publicação no Diário da Justiça 27 nov. 2014. Disponível em: <http://stj.jusbrasil.com.br/ jurisprudencia/153784360/recurso-especial-resp-1484674-pi-2014-01881188>. Acesso em: 17 mar. 2015.

. Supremo Tribunal Federal. Ag. Reg. no Inquérito 2.332 Distrito Federal. Relator: Ministro Celso de Mello. Julgado em 10 fev. 2011. Disponível em: $<$ http://redir.stf.jus.br/paginadorpub/ paginador.jsp?docTP=AC\&docID=619786> . Acesso em: 9 mar. 2015.

. Supremo Tribunal Federal. Reclamação 2138. Relator Ministro Nelson Jobim, Relator para Acórdão: Ministro Gilmar Mendes (ART.38,IV,b, DO RISTF), Tribunal Pleno, julgado em 13/06/2007. Disponível em: < http:// www.stf.jus.br/portal/processo/verProcessoAndamento.asp?numero=2138 $\&$ classe $=$ Rcl\&origem $=$ AP\&recurso $=0 \&$ tipoJulgamento $=\mathrm{M}>$. Acesso em: 15 mar. 2015.

CARVALHO FILHO, José dos Santos. Manual de direito administrativo. 25. ed. São Paulo: Atlas, 2012. 
DI PIETRO, Maria Sylvia Zanella. Direito administrativo. 26. ed. São Paulo: Atlas, 2013.

FAZZIO JÚNIOR, Waldo. Atos de improbidade administrativa: doutrina, legislação e jurisprudência. São Paulo: Atlas, 2008.

FIGUEIREDO, Marcelo. Probidade administrativa. 5. ed. São Paulo: Malheiros, 2004.

HOLANDA, Sérgio Buarque de. Raízes do Brasil. 26. ed. São Paulo: Companhia das Letras, 1995.

MEIRELLES, Hely Lopes. Direito administrativo brasileiro. 29. ed. São Paulo: Malheiros, 2004.

MELLO FILHO, José Celso de. Crime de responsabilidade: processo e julgamento de governador de estado. Justitia, São Paulo, v. 42, n. 109, p. 98, abr./jun. 1980.

MELLO, Celso Antonio Bandeira de. Curso de direito administrativo. 29. ed. São Paulo: Malheiros, 2012.

PAZZAGLINI FILHO, Marino. Lei de improbidade administrativa comentada. São Paulo: Atlas, 2007.

Artigo recebido em: 24/11/2015 Aprovado para publicação em: 29/11/2015

Como citar: BATISTI, Nélia Edna Miranda. PIMENTA, Julia Acioli. A aplicabilidade da Lei de Improbidade Administrativa aos agentes políticos. Revista do Direito Público. Londrina, v.10, n.3, p.119-140, set/ dez.2015. DOI: 10.5433/1980-511X.2015v10n3p119. ISSN: 1980-511X. 